\title{
Novel Antiviral Investigation of Annona squamosa Leaf Extract against the Dengue Virus Type-2: In Vitro Study
}

\author{
Arif Nur Muhammad Ansori' ${ }^{1}$, Amaq Fadholly' ${ }^{1}$ Annise Proboningrat ${ }^{1}$, Yulanda Antonius ${ }^{2 * *}$, Suhailah Hayaza ${ }^{3}$, \\ Raden Joko Kuncoroningrat Susilo ${ }^{3}$, Bilqis Inayatillah ${ }^{4}$, Mada Triandala Sibero ${ }^{5}$, Sin War Naw ${ }^{6}$, Gabrielle Ann \\ Villar Posa ${ }^{7}$, Teguh Hari Sucipto ${ }^{8, *}$, Soegeng Soegijanto ${ }^{8}$
}

\section{Arif Nur Muhammad Ansori', Amaq Fadholly', Annise Proboningrat ${ }^{1}$, Yulanda Antonius $^{2, *}$, Suhailah Hayaza ${ }^{3}$, Raden Joko Kuncoroningrat Susilo ${ }^{3}$, Bilqis Inayatillah ${ }^{4}$, Mada Triandala Sibero ${ }^{5}$, Sin War Naw ${ }^{6}$, Gabrielle Ann Villar Posa7, Teguh Hari Sucipto ${ }^{8, *}$, Soegeng Soegijanto ${ }^{8}$}

'Doctoral Program in Veterinary Science, Faculty of Veterinary Medicine, Universitas Airlangga, Surabaya, INDONESIA.

2Faculty of Biotechnology, University of

Surabaya, Surabaya, INDONESIA.

${ }^{3}$ Doctoral Program in Mathematics and Natural Sciences, Faculty of Science and

Technology, Universitas Airlangga, Surabaya INDONESIA.

${ }^{4}$ Master Program in Basic Medical Science, Faculty of Medicine, Universitas Airlangga Surabaya, INDONESIA.

${ }^{5}$ Department of Marine Science, Faculty of Fisheries and Marine Science, Universitas Diponegoro, Semarang, INDONESIA. ${ }^{6}$ Department of Chemistry, Myitkyina University, Myitkyina, MYANMAR ${ }^{7}$ School of Environmental Science and Management, University of the Philippines Los Baños, Los Baños, PHILIPPINES. ${ }^{8}$ Dengue Study Group, Institute of Tropical Disease, Universitas Airlangga, Surabaya, INDONESIA.

\section{Correspondence}

Teguh Hari Sucipto

Dengue Study Group, Institute of Tropical Disease, Universitas Airlangga, Surabaya, INDONESIA

E-mail: teguhharisucipto@staf.unair.ac.id Yulanda Antonius

Faculty of Biotechnology, University of Surabaya, Surabaya, INDONESIA.

E-mail: yulandaantonius@staff.ubaya.ac.id History

- Submission Date: 17-06-2020;

- Review completed: 16-07-2020.

- Accepted Date: 02-12-2020

DOI : 10.5530/pj.2021.13.58

Article Available online http://www.phcogj.com/v13/i2

\section{Copyright}

(C) 2021 Phcogj.Com. This is an openaccess article distributed under the terms of the Creative Commons Attribution 4.0 International license.

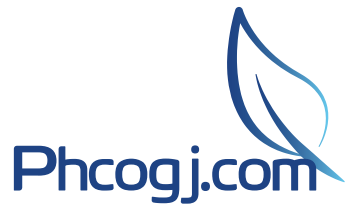

\section{ABSTRACT}

Introduction: Dengue virus (DENV) infection is general mosquito-transmitted viral taint. It can lead to the dengue hemorrhagic fever (DHF) or dengue shock syndrome (DSS). Dengue is a solemn illness with no endowed antiviral medication or recognized vaccine. Therefore, we aimed to investigate the activity of Annona squamosa leaf extract (ASLE) against dengue virus type-2 (DENV-2) isolated from Surabaya, Indonesia in 2013 (NCBI accession number: KT012509). Methods: In this study, the antiviral activity of ASLE was evaluated against DENV2 in Vero cells using Viral ToxGloTM Assay. In addition, we used CellTiter-Glo ${ }^{\circledR}$ Luminescent Cell Viability Assay to set the amount of viable cells in culture based on quantitation of the ATP. Results: DENV-2 replication inhibited by ASLE in Vero cells with $I C_{50}=73.78 \mu \mathrm{g} / \mathrm{mL}$ and $\mathrm{SI}=$ 4.49 when cells were treated two days after virus infection, whereas its $\mathrm{CC}_{50}$ for cytotoxicity to Vero cells was $331.54 \mu \mathrm{g} / \mathrm{mL}$. Interestingly, this is the first report on the investigation of ASLE against DENV-2. Conclusion: In summary, ASLE demonstrated the antiviral activity against DENV-2 with less toxicity, and high possibility as a drug candidate. Therefore, it might be suggested for in vivo assessment in the progress of a potent antiviral against DENV-2.

Key words: Annona squamosa, Antiviral activity, DENV-2, Vero cells.

\section{INTRODUCTION}

Dengue disease is a crucial mosquito-borne viral infectious disease in subtropical and tropical regions. Approximately, it reported about 350 million cases in global and more than 2.5 billion people are at high risk. ${ }^{1}$ Indonesia is a tropical country and it is common home of mosquito vector species of dengue virus (DENV), Aedes aegypti, and Aedes albopictus. ${ }^{2}$ The infection is caused by four DENV serotypes (DENV-1 to DENV-4) belonging to the Flaviviridae family. ${ }^{1} \mathrm{Up}$ to now, there is no effective an antiviral available for this dengue disease. ${ }^{2,3}$ However, the vaccination now had been trialed in several endemic countries, including Indonesia. ${ }^{4}$

Indonesia is a huge country in Southeast Asia with high of flora diversity in the world. There are more than 5,000 medicinal plants that available all around us. ${ }^{3}$ Consequently, medicinal plants are utilized by people for curing various diseases, including for viral related diseases. ${ }^{3,5,6,7}$ Various medicinal plants were found as an antiviral compounds, ${ }^{8}$ such as Amaryllidaceae, ${ }^{9}$ Annonaceae, ${ }^{10}$ Euphorbiaceae, ${ }^{11}$ and many others.

Annona squamosa leaves contain of several active compounds, such as phytosterols, flavonoids, alkaloids, saponins, glycoside, phenolic compounds, and tannins. Those compounds demonstrated the various therapeutic properties, such as an anticancer, antioxidant, antidiabetic, antimicrobial, antiviral, anti-inflammatory, and antimelanogenic activities. . $^{10,12,13,14,15}$ However, there are no reports regarding Annona squamosa leaf extract (ASLE) activity as an antiviral effect against DENV. Therefore, we aimed to investigate the activity of ASLE against DENV-2 isolated from Surabaya, Indonesia in 2013.

\section{MATERIALS AND METHODS}

\section{Chemical reagents}

The chemical reagents used in this study were the Minimum Essential Medium Eagle (MEM) (SigmaAldrich, USA), ethanol ( $\geq 99.8 \%$, Sigma-Aldrich, USA), trypsin-EDTA (Sigma-Aldrich, USA), dimethyl sulfoxide (DMSO) (Merck, Germany), penicillin-streptomycin (Gibco, USA), CellTiter-Glo Luminescent Cell Viability Assay (Promega, USA), fetal bovine serum (FBS) (Sigma-Aldrich, USA), and Viral ToxGlo ${ }^{\mathrm{m}}$ Assay reagents (Promega, USA).

Preparation of Annona squamosa leaf extract (ASLE)

Annona squamosa leaves were collected from Lumajang, East Java, Indonesia. Taxonomic identification of Annona squamosa was carried out by Purwodadi Botanical Garden, Indonesian Institute of Sciences, Purwodadi, Indonesia (approved with the reference number: 003/IPH.06.HM/VII/2017) The preparation of ASLE conducted according to Fadholly et al. (2020). ${ }^{6}$
Cite this article: Ansori ANM, Fadholly A, Proboningrat A, Antonius Y, Hayaza S, Susilo RJK, et al. Novel Antiviral Investigation of Annona squamosa Leaf Extract against the Dengue Virus Type-2: In Vitro Study. Pharmacog J. 2021;13(2): 456-62. 


\section{Preparation of Vero cells and DENV-2 isolate}

The Vero cells was purchased from ATCC: The Global Bioresource Center, USA which cultured in medium containing $2 \%$ penicillinstreptomycin and $10 \%$ FBS (Gibco, USA) and incubated at $37^{\circ} \mathrm{C}$ with $5 \% \mathrm{CO}_{2}$. A confluent monolayer of Vero cells was detached with trypsinEDTA and incubated at $37^{\circ} \mathrm{C}$ for 5 minutes. Furthermore, medium was added, pipet gently, and counted by using a hemocytometer (Paul Marienfeld, Germany). Cells were cultured into 96-well plate with density $1 \times 10^{6}$ cells $/ 10 \mathrm{~mL}$ and incubated at $37{ }^{\circ} \mathrm{C}$ with $5 \% \mathrm{CO}_{2}{ }^{16} . \mathrm{In}$ this study, we used DENV-2 which originally isolated from Surabaya, Indonesia. We used a clinical DENV-2 isolate identified by the Dengue Study Group, Institute of Tropical Diseases, Universitas Airlangga (NCBI accession number: KT012513). Previous study revealed that all DENV-2 strains isolated in Surabaya were classified into Cosmopolitan genotype. The clinical isolates propagated and maintained as previously described by Kotaki et al. (2016).$^{17}$ After titration of the virus isolate, the stocks were stored at $-80^{\circ} \mathrm{C}$ for further experiments.

\section{Cytotoxicity assay}

The confluent monolayers of Vero cells were prepared on a 96well plate $\left(1 \times 10^{5}\right.$ cells $\left./ \mathrm{mL}\right)$ as previously described by Untoro et al. (2019)..$^{18}$ We used CellTiter-Glo ${ }^{\otimes}$ Luminescent Cell Viability Assay (Promega, USA) in method to set the number of cells culture based on the ATP quantitation. Furthermore, CellTiter-Glo ${ }^{\circ}$ Luminescent Cell Viability Assay was addressed for cytotoxicity test by following the manufacturer's guidelines.

\section{Antiviral activity assay}

The confluent monolayers of Vero cells were prepared on a 96-well plate $\left(1 \times 10^{6}\right.$ cells $\left./ 10 \mathrm{~mL}\right)$, and the titer of DENV-2 was added in $2 \times 10^{4} \mathrm{FFU} /$ well. In this study, we used Viral ToxGlo ${ }^{\mathrm{mm}}$ Assay (Promega, USA) as a method intended to identify the cytopathic effect induced by a viral infection. In addition, we used Viral ToxGlo ${ }^{\mathrm{mm}}$ Assay reagents following the manufacturer's guidelines. Furthermore, the calculation of the selectivity index (SI) was defined as the comparison with ratio of $50 \%$ cytotoxic concentration $\left(\mathrm{CC}_{50}\right)$ and $50 \%$ antiviral concentration $\left(\mathrm{IC}_{50}\right)$ as previously stated by Zandi et al. (2012). ${ }^{19}$

\section{RESULTS AND DISCUSSION}

Dengue is a mosquito-borne disease whose broad incidence has upward dramatically in the last ten years. ${ }^{3,20}$ Indonesia is one of the greatest dengue-endemic nations in the worldwide which approximately 100,000 incidences of dengue are informed per annum. ${ }^{17}$ The East Java, West Java, and Central Java are considered for being the most prevalent province for dengue. ${ }^{21}$

Interestingly, in this study, we used DENV-2 isolate (NCBI accession number: KT012513) from the previous study conducted by Kotaki et al. (2016). ${ }^{17}$ It had a higher ratio of illness severity as compared to the other serotypes, such as DENV-1, DENV-3, and DENV-4 in Brazil. ${ }^{22}$ Recently, secondary infection with DENV-2, DENV-3, and DENV-4 increased the risk of severe dengue infection within Southeast Asia. Furthermore, DENV-2 in vitro proliferation was already established and standardized. ${ }^{23}$ In addition, we rendered molecular phylogenetic modeling and tree visualization by applying Molecular Evolutionary Genetics Analysis X (MEGA X) software with the maximum likelihood method based on the envelope glycoprotein gene from Indonesia and other countries (Figure 1). The phylogenetic tree was validated by performing the analysis on 1000 bootstrapped input datasets and crossreferencing with the Tamura-Nei substitution model. ${ }^{24}$

Nowadays, the use of traditional herbal medicines to manage various illness is accretion globally. ${ }^{3,7,25,26,27}$ Medicinal plants are a potential source for the development of new antiviral drugs. The plants contained of various chemical composition with the potency to prevent viral replication and control the viral infection. ${ }^{11}$ Plants have been considered to have an antiviral action and some have been accustomed to manage viral taints in humans and animals. In brief, the member of Annonaceae, Zingiberaceae, Cucurbitaceae, Fabaceae, Myrtaceae, Caricaceae, Meliaceae, Poaceae, Acanthaceae, Euphorbiaceae, Halymeniaceae, Piperaceae, and many other families have been reported as an antiDENV. ${ }^{8}$ However, up to now, there is no effective antiviral or vaccine available for the dengue disease. ${ }^{2}$

The research revealed that ASLE inhibited the DENV-2 in Vero cells with $\mathrm{IC}_{50}: 73.78 \mu \mathrm{g} / \mathrm{mL}, \mathrm{CC}_{50}: 331.54 \mathrm{c}$, and SI: 4.49 (Figure 2). Furthermore, we tested the ASLE activity in various concentrations and observed that ASLE exhibited low cytotoxicity effect within all evaluated concentrations (viability $>50 \%$ ) (Figure 3 ). In detail, we used various extract concentrations, such as $200 \mu \mathrm{g} / \mathrm{mL}, 100 \mu \mathrm{g} / \mathrm{mL}, 50 \mu \mathrm{g} /$ $\mathrm{mL}, 25 \mu \mathrm{g} / \mathrm{mL}, 12.5 \mu \mathrm{g} / \mathrm{mL}$, and $6.25 \mu \mathrm{g} / \mathrm{mL}$. The treatment of ASLE showed that the reduction of DENV-2 replication is demonstrated by the lowest concentration of extract $(6.25 \mu \mathrm{g} / \mathrm{mL})$. Our findings showed that ASLE exhibited the consequential antiviral action against DENV2 in Vero cells. Furthermore, this study also suggested the leading antiviral activity of ASLE is possible in consequence of its action towards the stages of intracellular replication of the virus in place of the early stages of its replication sequence such as virus entry. Nevertheless, the completed frameworks of the activity required to be discovered for an anti-DENV medication. Further investigation might be applied by using the suitable model, for example cultured human cells.

Annona is one of 129 genera of the Annonaceae family which contained of 119 species. Annona squamosa is commonly called by people

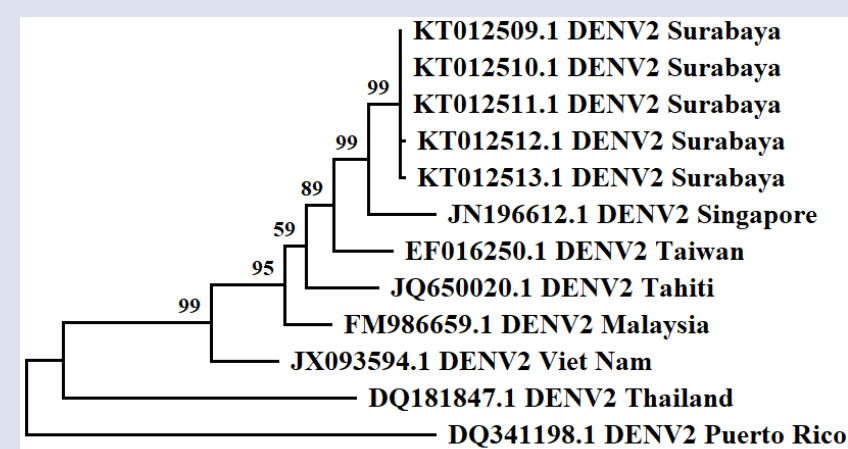

0.01

Figure 1: Molecular phylogenetic tree of DENV-2 isolates from Surabaya, Indonesia and other countries.

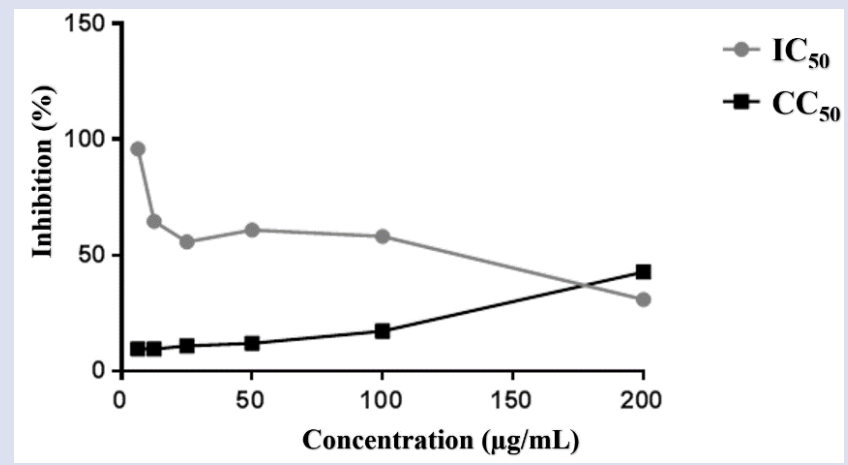

Figure 2: $I C_{50}$ and $C C_{50}$ of ASLE against DENV-2 in Vero cells. 

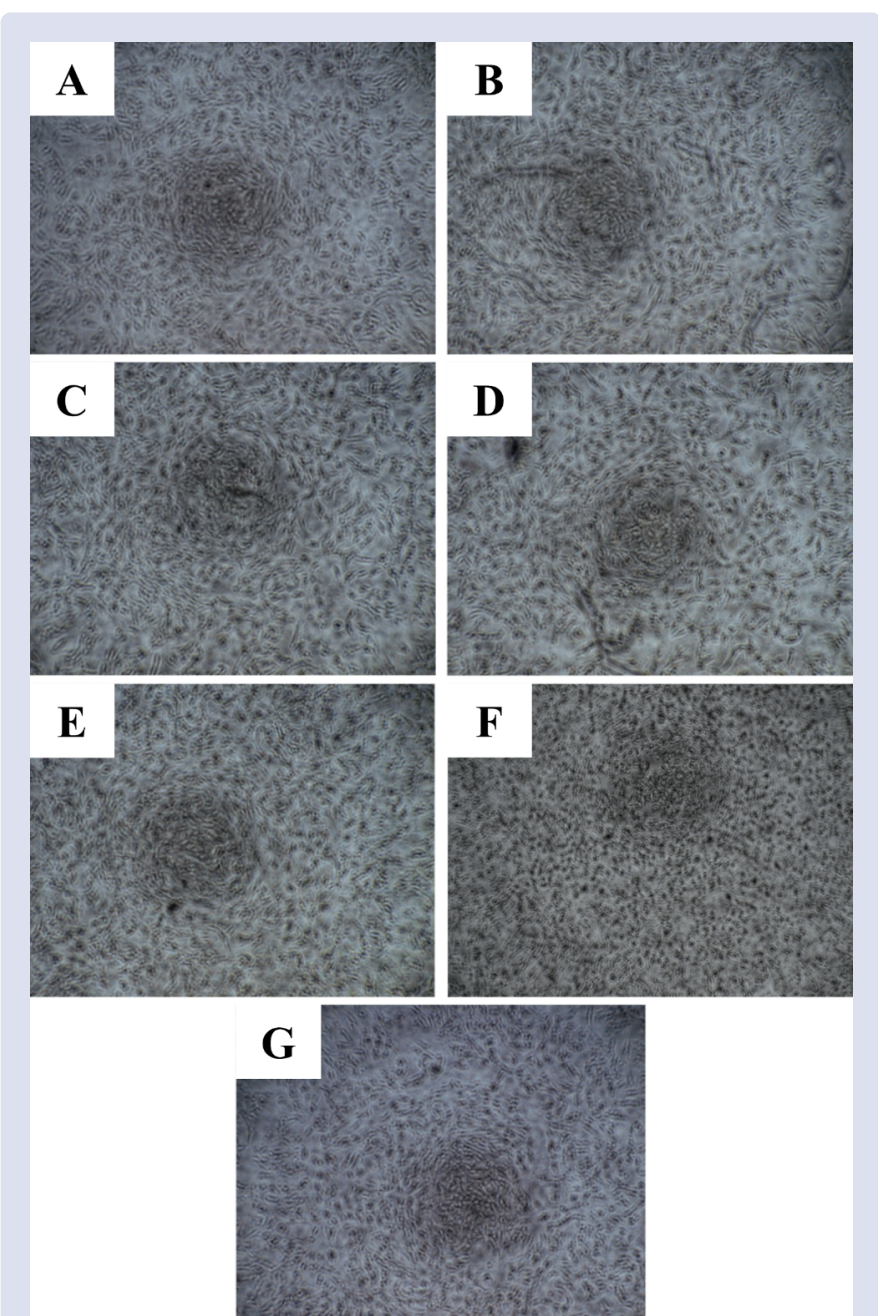

Figure 3: Evaluation of the anti-DENV-2 activity of ASLE in Vero cells. A: $6.25 \mu \mathrm{g} / \mathrm{mL}$ of ASLE, B: $12.5 \mu \mathrm{g} / \mathrm{mL}$ of ASLE, C: $25 \mu \mathrm{g} / \mathrm{mL}$ of ASLE, D: 50 $\mu \mathrm{g} / \mathrm{mL}$ of ASLE, E: $100 \mu \mathrm{g} / \mathrm{mL}$ of ASLE, F: $200 \mu \mathrm{g} / \mathrm{mL}$ of ASLE, G: Control.

as srikaya (Indonesia) or sugar apple (English). ${ }^{28}$ It is also known for its delicious sweet taste..$^{29}$ The Province of East Java, Indonesia is considered as the endemic of Annona squamosa even though it is widely distributed to all the regions. The fruit is marketed as family fruit for daily consumption or as a source of the other food products in the home industry. ${ }^{30}$ On the other hand, phytochemical screening of ASLE showed the availability of acetogenins, alkaloids, flavonoids, glycosides, phenolic, saponins, steroids, tannins, terpenoids, and many other compounds. ${ }^{6,10,29,31}$ Therefore, Annona squamosa considered as the medicinal plant for many diseases, such as cancer, cardiac disease, diabetes, mucous diarrhea, and many other diseases. ${ }^{6,29}$

According to the ASLE, previous research revealed that the cytotoxic effect of chitosan-based nanoparticles of ASLE on cervical cancer cells (HeLa) had an $\mathrm{IC}_{50}$ value with $344.48 \mu \mathrm{g} / \mathrm{mL}$ in concentration. ${ }^{6}$ Even though, many studies on the biological effects of Annona squamosa were conducted, there are only two reports have shown Annona squamosa as an antiviral against HIV $^{31}$ and avian influenza virus. ${ }^{10}$ Furthermore, Lisina and Piramanayagam (2014) also demonstrated its binding properties by the in silico study between the HIV protease and chemical compound of Annona squamosa. ${ }^{31}$ Yunita et al. (2019) stated that the most effective concentration of Annona squamosa seeds extract is $0.35 \mu \mathrm{g} / \mathrm{mL}$. The inhibition mechanism of the extract was performed by interfering the attachment and reducing the viral replication. The flavonoids were suspected to have a mechanism for interfering the viral replication by inhibit the viral reverse transcriptase enzymes which resulted in blockade synthesis of an virus RNA. ${ }^{10}$

Moreover, compound which considered as a drug should have the cytotoxic activity only at high concentrations and activity at very low concentrations counter the virus. In brief, it consequently acquiescent a high SI rate and capable to eradicate the DENV at concentrations well below its cytotoxic concentration. ${ }^{19}$ In addition, the SI of a compound is a highly fulfilled as a variable accustomed to declare the in vitro effectiveness toward the virus replication inhibition. Moreover, the establishment of new antiviral invention from bioactive composition is indispensable in pursuance of more potent and less toxic antiviral drugs. ${ }^{16}$

\section{CONCLUSION}

In summary, ASLE demonstrated the antiviral activity against the DENV-2 with less toxicity, and high possibility to be considered as a drug candidate. Therefore, in vivo assessment might need to be conducted for further DENV-2 antiviral identification.

\section{ACKNOWLEDGMENT}

We thank EJA Team, Indonesia for editing the manuscript. This study supported by the Center of Excellence (COE) Program, Ministry of Research and Technology/National Agency for Research and Innovation (Kemenristek/BRIN) of the Republic of Indonesia and PMDSU Scholarship - Batch III by the Directorate General of Higher Education, Ministry of Education and Culture of the Republic of Indonesia.

\section{DISCLOSURE STATEMENT}

The authors have no conflicts of interest to declare.

\section{ABBREVIATIONS}

ASLE: Annona squamosa leaf extract; ATP: Adenosine triphosphate; $\mathrm{CC}_{50}: 50 \%$ cytotoxic concentration; $\mathrm{CO}_{2}$ : Carbon dioxide; DENV: Dengue virus; DENV-2: Dengue virus type-2; DMSO: Dimethyl sulfoxide; EDTA: Ethylenediaminetetraacetic acid; FBS: Fetal bovine serum (FBS); HIV: Human immunodeficiency virus; $\mathrm{IC}_{50}$ : 50\% antiviral concentration; MEGA X: Molecular Evolutionary Genetics Analysis X; MEM: Minimum Essential Medium Eagle; SI: Selectivity index.

\section{REFERENCES}

1. Astuti EP, Dhewantara PW, Prasetyowati H, Ipa M, Herawati C, Hendrayana K. Paediatric dengue infection in Cirebon, Indonesia: A temporal and spatial analysis of notified dengue incidence to inform surveillance. Parasit Vectors. 2019;12(1):186.

2. Ansori ANM, Kusala MKJ, Irawan $H$, Putri N, Fadholly A, Proboningrat A, et al. Citrus reticulata extract as biocides to control Aedes aegypti, the vector of dengue. Biosci Res. 2018;15:1661-5

3. Ansori ANM, Fadholly A, Proboningrat A, Jayanti S, Hayaza S, Susilo RJK, et al. Efficacy of Allium cepa (Amaryllidaceae) extract against dengue virus type-2 (Flaviviridae: Flavivirus) isolated from Surabaya, Indonesia. Biochem Cell Arch. 2020;20(2):4783-6.

4. Arredondo-García JL, Hadinegoro SR, Reynales H, Chua MN, Rivera Medina DM, Chotpitayasunondh T, et al. Four-year safety follow-up of the tetravalent dengue vaccine efficacy randomized controlled trials in Asia and Latin America. Clin Microbiol Infect. 2018;24(7):755-63.

5. Ansori ANM, Susilo RJK, Hayaza S, Winarni D, Husen SA. Renoprotection by Garcinia mangostana L. pericarp extract in streptozotocin-induced diabetic mice. Iraqi J Vet Sci. 2019;33(1):13-9.

6. Fadholly A, Ansori ANM, Proboningrat A, Nugraha AP, Iskandar RPD, Rantam FA, Sudjarwo SA. Apoptosis of HeLa cells via caspase-3 expression induced by chitosan-based nanoparticles of Annona squamosa leaf extract: In vitro study. Indian J Pharm Educ Res. 2020;54(2):416-21.

7. Husen SA, Syadzha MF, Setyawan MF, Pudjiastuti P, Ansori ANM, Susilo RJK, et al. Evaluation of the combination of Sargassum duplicatum, Sargassum ilicifolium, Abelmoschus esculentus, and Garcinia mangostana extracts for open wound healing in diabetic mice. Sys Rev Pharm. 2020;11(9):888-92. 
8. Abd Kadir SL, Yaakob H, Mohamed Zulkifli R. Potential anti-dengue medicinal plants: A review. J Nat Med. 2013;67(4):677-89.

9. Lee JB, Miyake S, Umetsu R, Hayashi K, Chijimatsu T, Hayashi T. Anti-influenza A virus effects of fructan from Welsh onion (Allium fistulosum L.). Food Chem. 2012;134(4):2164-8

10. Yunita MN, Raharjo AP, Wibawati PA, Agustono B. Antiviral activity of ethanolic extract of srikaya seeds (Annona squamosa L.) against avian influenza virus. Indian Vet J. 2019;96:26-9.

11. Klawikkan N, Nukoolkarn V, Jirakanjanakir N, Yoksan S, Wiwatland C, Thirapanmethee K. Effect of Thai medicinal plant extracts against dengue virus in vitro. Mahidol Univ J Pharm Sci. 2011;38:13-8.

12. Tomar RS, Sisodia SS. Antidiabetic activity of Annona squamosa Linn. in alloxan-induced diabetic rats. Int J Green Pharm. 2014;8(4):237-41.

13. Hendawy OM, ELBana MA, Abdelmawlla HA, Maliyakkal N, Mostafa-Hedeab G. Effect of Annona squamosa ethanolic and aqueous leave extracts on aluminum chloride-induced neuroinflammation in albino rats. Biomed Pharmacol J. 2019;12(04):1723-30.

14. Ko GA, Kang HR, Moon JY, Ediriweera MK, Eum S, Bach TT, Cho SK. Annona squamosa L. leaves inhibit alpha-melanocyte-stimulating hormone ( $\alpha$-MSH) stimulated melanogenesis via p38 signaling pathway in B16F10 melanoma cells. J Cosmet Dermatol. 2020;19(7):1785-92.

15. Ruddaraju LK, Pallela PN, Pammi SV, Padavala VS, Kolapalli VR. Synergetic antibacterial and anticarcinogenic effects of Annona squamosa leaf extract mediated silver nano particles. Mater Sci Semicond Process. 2019;100:301-9.

16. Sucipto TH, Churrotin S, Setyawati $H$, Martak F, Mulyatno KC, Amarullah IH, et al. A new copper (II)-imidazole derivative effectively inhibits replication of DENV-2 in Vero cell. Afr J Infect Dis. 2018;12(1 Suppl):116-9.

17. Kotaki T, Yamanaka A, Mulyatno KC, Churrotin S, Sucipto TH, Labiqah A, et al. Divergence of the dengue virus type 2 Cosmopolitan genotype associated with two predominant serotype shifts between 1 and 2 in Surabaya, Indonesia, 2008-2014. Infect Genet Evol. 2016;37:88-93.

18. Untoro YM, Sucipto TH, Setyawati H, Maharani A, Sholihah NF, Churrotin S, et al. In vitro study: Effect of cobalt (II) chloride against dengue virus type 1 in Vero cells. Indonesian J Pharm. 2019;30(4):316-20.

19. Zandi K, Teoh BT, Sam SS, Wong PF, Mustafa MR, Abubakar S. Novel antiviral activity of baicalein against dengue virus. BMC Complement Altern Med. 2012;12:214.
20. Utama IMS, Lukman N, Sukmawati DD, Alisjahbana B, Alam A, Murniati D, et al. Dengue viral infection in Indonesia: Epidemiology, diagnostic challenges, and mutations from an observational cohort study. PLoS Negl Trop Dis. 2019;13(10):e0007785.

21. Harapan H, Michie A, Mudatsir M, Sasmono RT, Imrie A. Epidemiology of dengue hemorrhagic fever in Indonesia: Analysis of five decades data from the National Disease Surveillance. BMC Res Notes. 2019;12(1):350.

22. Vicente $\mathrm{CR}$, Herbinger $\mathrm{KH}$, Fröschl G, Malta Romano C, de Souza Areias Cabidelle A, Cerutti Junior C. Serotype influences on dengue severity: A crosssectional study on 485 confirmed dengue cases in Vitória, Brazil. BMC Infect Dis. 2016;16:320

23. Euanorasetr J, Intra B, Thunmrongsiri N, Limthongkul J, Ubol S, Anuegoonpipat $A$, et al. In vitro antiviral activity of spirotetronate compounds against dengue virus serotype 2. J Gen Appl Microbiol. 2019;65(4):197-203.

24. Turista DDR, Islamy $A$, Kharisma VD, Ansori ANM. Distribution of COVID-19 and phylogenetic tree construction of SARS-CoV-2 in Indonesia. J Pure Appl Microbiol. 2020;14:1035-42.

25. Hayaza S, Istiqomah S, Susilo RJK, Inayatillah B, Ansori ANM, Winarni D, et al. Antidiabetic activity of ketapang (Terminalia catappa L.) leaves extract in streptozotocin-induced diabetic mice. Indian Vet J. 2019;96:11-3.

26. Sukardiman, Ervina M. The recent use of Swietenia mahagoni (L.) Jacq as antidiabetes type 2 phytomedicine: A systematic review. Heliyon. 2020;6(3):e03536.

27. Tacharina MR, Ansori ANM, Plumeriastuti $H$, Kusnoto, Kurnijasanti R, Hestianah EP. Beneficial effect of grinting grass (Cynodon dactylon) on the streptozotocin induced diabetes mellitus in the mice. Indian Vet J. 2020;97(4):35-8.

28. Nugraha AS, Damayanti YD, Wangchuk P, Keller PA. Anti-infective and anticancer properties of the Annona species: Their ethnomedicinal uses, alkaloid diversity, and pharmacological activities. Molecules. 2019;24(23):4419.

29. Nagori R, Sharma P, Purohit SD. Molecular characterization of diversity in Annona squamosa L.: A high value tropical medicinal plant. Int J Phytocos Nat Ingred. 2018;5(1):4.

30. Masruri, Sharma M, Warsito, Adi P. Renewable oil extracted from Indonesian srikaya's (Annona squamosa sp.) seed: Another potent source for biodiesel. J Pure Appl Chem Res. 2012;1(1):51-7.

31. Lisina KV, Piramanayagam S. An insilico study on HIV-1 protease wild-type and mutant with inhibitors from Annona squamosa. Int J Pharm Sci Res. $2014 ; 5: 1811-8$ 


\section{GRAPHICAL ABSTRACT}

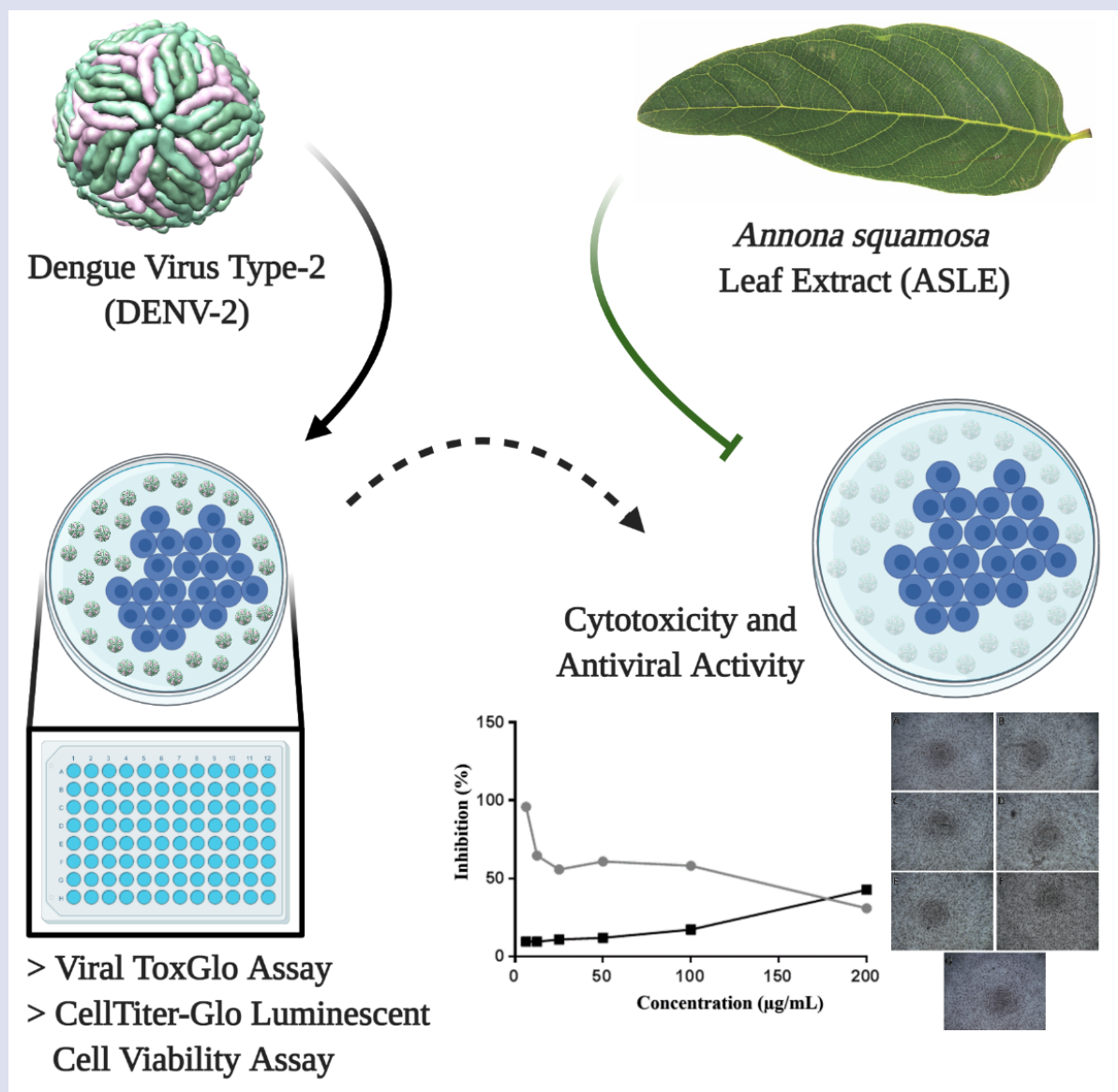

\section{ABOUT AUTHORS}

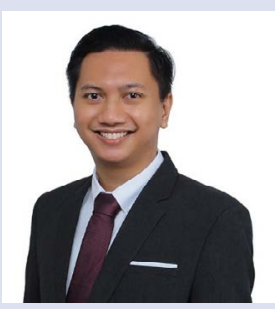

Arif Nur Muhammad Ansori is a Ph.D. candidate in Veterinary Science at Universitas Airlangga. He completed his B.Sc. in Biology and M.Sc. in Vaccinology and Immunotherapeutics at Universitas Airlangga. Currently, he is an awardee of PMDSU Scholarship (Batch III) at Universitas Airlangga. His research projects related to virology, bioinformatics, and molecular biology. His actual research focus is the application of molecular biology to the development of a novel bivalent vaccine against COVID-19.

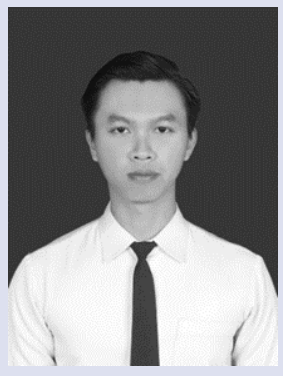

Amaq Fadholly is a Ph.D. candidate in Veterinary Science at Universitas Airlangga, Indonesia. His research area focuses on the natural products for cancer, pharmacology, and veterinary reproduction. 

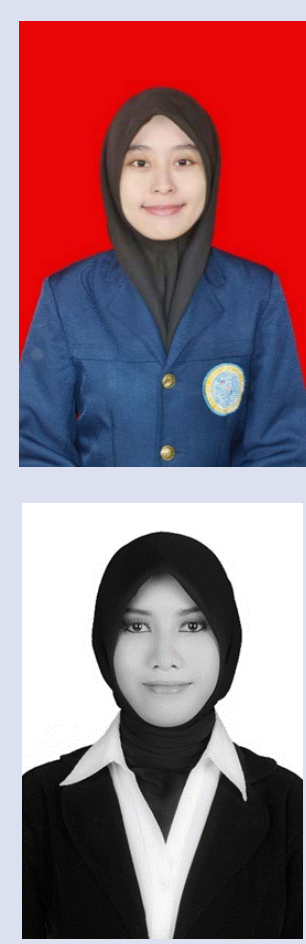

Yulanda Antonius received her B.Sc. in Biology, University of Brawijaya, Indonesia and M.Sc. in Medical Science, University of Tsukuba, Japan. She embroiled in various research about cell biology, molecular biology, and bioinformatics. Currently, she works as a lecturer at the University of Surabaya, Indonesia and concerns with the molecular biology research.
Annise Proboningrat is a Ph.D. candidate in Veterinary Sciences, Faculty of Veterinary Medicine, Universitas Airlangga. The doctoral research focused on the synthesize of natural compounds loaded in polymeric nanoparticles and its potency as novel anticancer candidate.

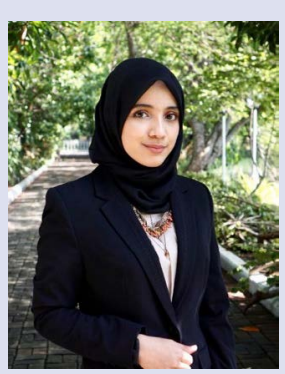

Suhailah Hayaza has interests in immunology, bio-medicine, data analysis, and public speaking. Currently, she is an active researcher and doctorate candidate at Universitas Airlangga, notable as one of the youngest Ph.D. candidates in Biology. Her projects are related to immunology, cancer, and the use of the natural product as medical treatment (nutraceutical). She often works on cell culture, ELISA, flow cytometry, immunocyto/histochemistry, natural product extraction, MTT assay, western blotting, and handling mice for in vivo purposes. At the moment, she has reached an h-index of 7 in Scopus and Google Scholar, with over 22 papers published.

Raden Joko Kuncoroningrat Susilo is a Ph.D. candidate in Department of Biology, Faculty of Science and Technology, Universitas Airlangga. He completed his B.Sc. and M.Sc. degree also in Biology, Universitas Airlangga. Currently, he works in potential of natural plant for fibrosis and cancer treatment, especially on liver fibrosis and liver cancer.

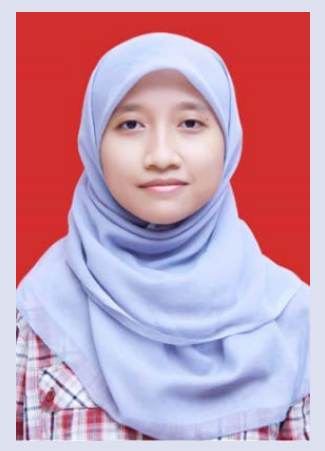

Bilqis Inayatillah has graduated from Universitas Airlangga (Bachelor in Biological Science). Today, she is studying Basic Medical Science (Master Program) at Faculty of Medicine, Universitas Airlangga. She was concerned about the disease, the mechanism and treatments. Her study scopes including in diabetes, pharmacology, pathology and biochemistry. Beside her studying program she was also a publication staff at Publication Center, Faculty of Dental Medicine, Universitas Airlangga. 

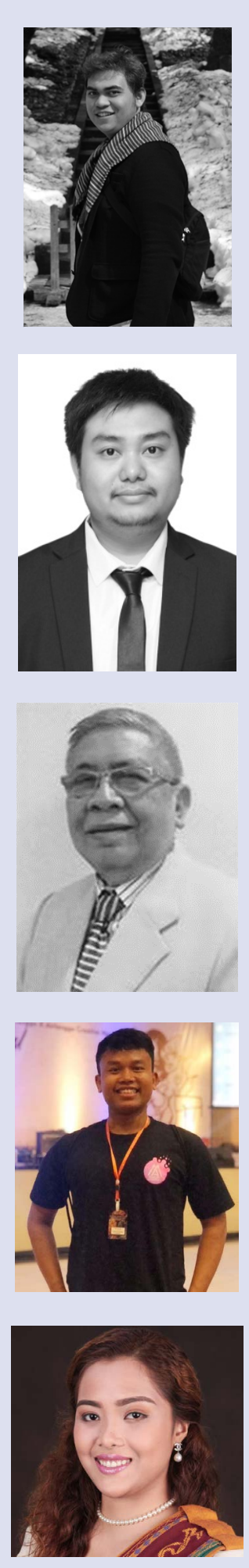

Mada Triandala Sibero is a lecturer at the Department of Marine Science, Universitas Diponegoro, Semarang, Indonesia. Mainly, he works with DNA barcoding to discover the diversity of marine fungi and actinobacteria from neglected resources and or environment then study their metabolites. He also works with natural products from macro-organisms but not limited to marine organisms.

Teguh Hari Sucipto was completed Bachelor of Science at the Department of Chemistry, Universitas Airlangga, takes an interest in Analytical Chemistry and the graduate at the Department of Chemistry, Institut Teknologi Sepuluh Nopember, takes an interest in Inorganic Chemistry. Currently, he is a researcher at the Dengue Laboratory, Institute of Tropical Disease, Universitas Airlangga with the focus research in virology, cell-based bioassay, and epidemiology. The author was published 16 manuscripts in Scopus journal indexed and also 4 h-index.

Soegeng Soegijanto is an Emeritus Professor at the Faculty of Medicine, Universitas Airlangga. He is a Leader of the Dengue Study Group, Institute of Tropical Disease, Universitas Airlangga. 26 international scientific publications were published in the field of dengue include Continuous Dengue Type 1 Virus Genotype Shifts Followed by Co-Circulation, Clade Shifts and Subsequent Disappearance in Surabaya, Indonesia, 2008-2013. Some of the titles of books that have been written are "Dengue Hemorrhagic Fever" and "Collection of Papers: Tropical Diseases and Infections in Indonesia".

Sin War Naw is a lecturer/researcher in the Department of Chemistry, Myitkyina University, Myitkyina, Myanmar.

Gabrielle Ann Villar Posa is a graduate student in the School of Environmental Science and Management, University of the Philippines Los Baños, Los Baños, Philippines.

Cite this article: Ansori ANM, Fadholly A, Proboningrat A, Antonius Y, Hayaza S, Susilo RJK, et al. Novel Antiviral Investigation of Annona squamosa Leaf Extract against the Dengue Virus Type-2: In Vitro Study. Pharmacog J. 2021;13(2): $456-62$. 